\title{
Cr (VI) Removal Using Cow Bone Waste Adsorbent
}

\author{
Raden Kokoh Haryo Putro \\ Department of Environmental Engineering \\ Universitas Pembangunan Nasional "Veteran" Jawa Timur \\ Surabaya, Indonesia
}

\author{
Vansa Nopy Rahardi, Okik Hendriyanto \\ Cahyonugroho ${ }^{1}$, Aussie Amalia \\ Department of Environmental Engineering \\ Universitas Pembangunan Nasional "Veteran" Jawa Timur \\ Surabaya, Indonesia \\ 1okhecah@gmail.com
}

\begin{abstract}
Pollution caused by $\mathrm{Cr}(\mathrm{VI})$ metal is harmful because it is toxic and carcinogenic. Utilization of cow bone waste is considered not optimal. One of the utilization is as an adsorbent of $\mathrm{Cr}$ (VI) metal. This research aims to determine the adsorption capacity by bone waste bone adsorbent in lowered $\mathrm{Cr}(\mathrm{VI})$ metal, and to determine the adsorption isotherm model. Cow bone waste carbonized with furnace at a temperature of $800^{\circ} \mathrm{C}$ for 1 hour until it became charcoal. A size of 100 mesh and $\mathrm{Na}_{2} \mathrm{CO}_{3} 5 \%$ activator were used and soak for 24 hours. In this research, shaker and waste simulation were used in batch method. Variations used include variation of mass of adsorbent (gram) : 0,$4 ; 0.6 ; 0.8 ; 1 ; 1,2$ and stirring time (minutes) : 15, 30, $60,90,120$. The analyzed parameters were $\mathrm{Cr}(\mathrm{VI})$ metal concentrations. The research result showed that percent removal in optimum condition of adsorption adsorbent using cow bone waste at mass of 1,2 gram with stirring time 90 minutes was $66,92 \%$ for the non-activated adsorbent and $82,20 \%$ of percent removal at mass 1,2 gram with stirring time 120 minutes for the activated adsorbent. The adsorption isotherm followed the Freundlich model with the value $R 2=0,9968$ for the nonactivated adsorbent and the value of $R 2=0,9909$ for the activated adsorbent.
\end{abstract}

\section{Keywords - adsorption; cow bone waste; $\mathrm{Cr}(\mathrm{VI})$ metal}

\section{INTRODUCTION}

Industrial activities besides aiming to increase prosperity, also produce waste as an environmental polluter. waste water generated from industrial activities contributes to release of harmful heavy metals in the water. It caused a negative impact on organism in the ecosystem. One of the dangerous heavy metals is chromium. Biologically, chromium is inactive in a metallic state. In the state of $\mathrm{Cr}$ (VI) hexavalent chromium, it is more dangerous because it can penetrate organs or cells more easily [1]. The levels of Chromium in water can poison humans, especially hexavalent chromium [Cr (VI)]. the level of heavy metals $\mathrm{Cr}$ (VI) in industrial wastewater discharged into the river can be a serious problem. Heavy metals are very toxic and carcinogenic even in relatively low concentrations [2]. Diseases caused by heavy metals Cr (VI) are abdominal pain, ulcers, respiratory problems, a weakened immune system, kidney and liver damage, lung cancer, and death.

Alternative treatment for heavy metal waste is the use of natural materials as adsorbents. Based on previos research showed that the main preparation of bone is tricalcium phosphate and calcium carbonate which have the potential as adsorbents. Physically, bones have pores that can adsorb other substances into the surface of their pores. Cow bone had the potential to be used as an adsorbent [3]. Other studies showed that bone charcoal had a high adsorption capacity in absorbing $\mathrm{Zn}$ and $\mathrm{Cu}$. $\mathrm{Zn}$ and $\mathrm{Cu}$ are heavy metals [4].

Based on the problem, this study was conducted to determine the adsorption power of the simulated wastewater of hexavalent chromium [Cr (VI)] by utilizing cow bone waste as adsorbent and activated by sodium carbonate $\left(\mathrm{Na}_{2} \mathrm{CO}_{3}\right)$.

\section{RESEACRH METHODS}

\section{A. Research Material and Tools}

The tools and materials to be used in this research were cow bone waste, $\mathrm{K}_{2} \mathrm{Cr}_{2} \mathrm{O}_{7}$ powder, $\mathrm{Na}_{2} \mathrm{CO}_{3}$ powder, aquadest, simulation of $\mathrm{Cr}$ (VI) liquid waste, shaker, $\mathrm{pH}$ meter, filter paper, 100 mesh sieve, furnace, oven, grinder, erlenmeyer, desiccators, analytic scales, and spectrophotometers.

\section{B. Research Procedure}

1) Process of Making Adsorbents: The material used for adsorbents was cow bone waste. The cow bone was taken from the restaurant waste in Kureksari Village, Waru District, Sidoarjo Regency. Bones were washed and cleaned from sticking dirt. The material was dried at room temperature. then, the material was cut into small pieces using a grinder. The pieces were dehydrated using an oven for 1 hour at $105^{\circ} \mathrm{C}$. After that it was carbonized in the furnace at $800^{\circ} \mathrm{C}$ for 1 hour to become charcoal. Cow bone charcoal was cooled in a desiccator for 30 minutes. Then the charcoal was pounded and sieved using a 100 mesh sieve. The charcoal was activated with a $5 \% \quad \mathrm{Na}_{2} \mathrm{CO}_{3}$ activator solution for 24 hours. Comparison of charcoal mass and activator volume was 10 grams of charcoal soaked in $100 \mathrm{ml}$ of activator. Then the solution was filtered with filter paper and the residue on filter paper is dried in an oven for 30 minutes at $105^{\circ} \mathrm{C}$. After drying, the calcination process was carried out in the furnace at $800^{\circ} \mathrm{C}$ for 30 minutes and cooled in a desiccator. Activated charcoal was washed with aquadest repeatedly until neutral 
$\mathrm{pH}$ and dried in an oven at $105^{\circ} \mathrm{C}$ for 1 hour. And activated charcoal from cow bone waste was ready to be characterized.

2) Testing of Adsorbent Absorption Capacity Against Cr (VI): Prepare erlenmeyer $250 \mathrm{ml}$. Take $100 \mathrm{ml}$ of $\mathrm{Cr}$ (VI) waste samples with a concentration of $200 \mathrm{ppm}$ and put in each erlenmeyer. Weighing the activated charcoal of cow bone waste with adsorbent mass variation $0.4 ; 0.6 ; 0.8 ; 1 ; 1,2$ (gram) and put into each erlenmeyer which contains $\mathrm{Cr}$ (VI) simulation waste sample. Then shaken using a shaker with a stirring speed of $150 \mathrm{rpm}$ with a variation of time stirring 15 , 30, 60, 90, 120 (minutes). After the shaker process was complete, the sample is left for 10 minutes. Then filtered with filter paper and filtered sample water was taken to analyze $\mathrm{Cr}$ (VI) levels.

$$
\% \text { Removal }=\frac{\mathrm{Co}-\mathrm{Ce}}{\mathrm{Co}} \times 100 \%
$$

Information:

$\mathrm{Co}=$ Initial Concentration $\mathrm{Cr}(\mathrm{VI})$

$\mathrm{Ce}=$ Final Concentration $\mathrm{Cr}(\mathrm{VI})$

3) Calculation of adsorption capacity: Calculation of adsorbent capacity can use modeling of Langmuir and Freundlich isotherms. The Langmuir isotherm model defines that the maximum adsorption capacity occurs due to the presence of a single layer (monolayer) of the adsorbate on the surface of the adsorbent. Langmuir isotherm is used to describe the limitation of the active side of adsorption. the active side of the adsorbent is assumed to be homogeneous and has the same energy in adsorbing adsorbate [5].

Freundlich's isotherm model explains that the adsorption process on the surface is heterogeneous where not all surfaces of the adsorbent have adsorption power and the repulsion force between the adsorbate molecules. The Freundlich isotherm equation is based on the assumption that adsorption occurs on several surface layers (multilayer). Because of the bond between adsorbate and adsorbent by Van Der Waals force, so the bond is not too strong. It is related to the characteristics of physical adsorption where adsorption can occur in many layers (multilayer). Freundlich's isotherm equation explains that the adsorbent surface is heterogeneous, meaning that each active group on the surface of the adsorbent has the ability to adsorb differently [5].

\section{RESULT AND DISCUSSION}

\section{A. Preliminary Analysis of Research}

Based on the initial laboratory analysis, the initial content of $\mathrm{Cr}$ (VI) waste was $193.8 \mathrm{mg} / 1$ with a $\mathrm{pH}$ of 4.9. Adsorbent of cow bone waste was expected to adsorb $\mathrm{Cr}$ (VI) content in waste simulation. Characterization of adsorbent of cow bone waste in the form of activated charcoal aimed to determine the physical and chemical properties of activated charcoal that will be used in the adsorption process. The method used in determining water content and active charcoal ash content of cow bone waste is the gravimetric method, in which chemical analysis is based on weighing differences in initial sample weights and final sample weights after treatment. Results of analysis of water content and levels of charcoal ash (activated and not) were in accordance with SNI No. 06-3730-1995. For the value of activated charcoal water content without activation, it had a higher moisture content of $6.7 \%$ compared to the activated charcoal water content of $5 \% \mathrm{Na}_{2} \mathrm{CO}_{3}$ which is $6.2 \%$ with a maximum quality requirement of $15 \%$. Whereas, the value of activated charcoal ash without activation had a higher ash content of $9.6 \%$ compared to the activated charcoal ash value of $5 \% \mathrm{Na}_{2} \mathrm{CO}_{3}$ which is $8.3 \%$ with a maximum quality requirement of $10 \%$.

TABLE I. RESUlts OF CR (VI) METAL Test ANALYSIS With ADSORBENT WITHOUT ACTIVATION

\begin{tabular}{|c|c|c|c|}
\hline $\begin{array}{l}\text { Adsorbent } \\
\text { Mass } \\
\text { (gram) }\end{array}$ & $\begin{array}{l}\text { Stirring } \\
\text { Time } \\
\text { (minutes) }\end{array}$ & $\begin{array}{c}\text { Final Cr(VI) } \\
\text { Concentration } \\
(\mathrm{mg} / \mathrm{l})\end{array}$ & $\begin{array}{c}\text { Removal } \\
\text { Cr(VI) } \\
(\%)\end{array}$ \\
\hline \multirow{5}{*}{0.4} & 15 & 124.7 & 35.66 \\
\hline & 30 & 121.2 & 37.46 \\
\hline & 60 & 118.6 & 38.80 \\
\hline & 90 & 107.7 & 44.43 \\
\hline & 120 & 108.2 & 44.17 \\
\hline \multirow{5}{*}{0.6} & 15 & 119.6 & 38.29 \\
\hline & 30 & 117.7 & 39.27 \\
\hline & 60 & 110.4 & 43.03 \\
\hline & 90 & 101.2 & 47.78 \\
\hline & 120 & 102.4 & 47.16 \\
\hline \multirow{5}{*}{0.8} & 15 & 110.7 & 42.88 \\
\hline & 30 & 106.1 & 45.25 \\
\hline & 60 & 90.5 & 53.30 \\
\hline & 90 & 89.2 & 53.97 \\
\hline & 120 & 93.3 & 51.86 \\
\hline \multirow{5}{*}{1.0} & 15 & 96.0 & 50.46 \\
\hline & 30 & 85.0 & 56.14 \\
\hline & 60 & 79.4 & 59.03 \\
\hline & 90 & 72.9 & 62.38 \\
\hline & 120 & 79.7 & 58.88 \\
\hline \multirow{5}{*}{1.2} & 15 & 82.4 & 57.48 \\
\hline & 30 & 78.5 & 59.49 \\
\hline & 60 & 74.8 & 61.40 \\
\hline & 90 & 64.1 & 66.92 \\
\hline & 120 & 68.7 & 64.55 \\
\hline
\end{tabular}

TABLE II. Results OF ANALySIS OF CR (VI) METAl TEST WITH ACTIVATED ADSORBENTS

\begin{tabular}{|c|c|c|c|}
\hline $\begin{array}{c}\text { Adsorbent } \\
\text { Mass } \\
\text { (gram) }\end{array}$ & $\begin{array}{c}\text { Stirring } \\
\text { Time } \\
\text { (minutes) }\end{array}$ & $\begin{array}{c}\text { Final Cr(VI) } \\
\text { Concentration } \\
(\mathrm{mg} / \mathrm{l})\end{array}$ & $\begin{array}{c}\text { Removal } \\
\text { Cr(VI) } \\
(\%)\end{array}$ \\
\hline \hline \multirow{4}{*}{0.4} & 15 & 98.5 & 49.17 \\
\cline { 2 - 4 } & 30 & 94.0 & 51.50 \\
\cline { 2 - 4 } & 60 & 91.8 & 52.63 \\
\cline { 2 - 4 } & 90 & 89.2 & 53.97 \\
\hline \hline
\end{tabular}




\begin{tabular}{|c|c|c|c|}
\hline \multirow[t]{2}{*}{$\begin{array}{c}\text { Adsorbent } \\
\text { Mass } \\
\text { (gram) }\end{array}$} & $\begin{array}{l}\text { Stirring } \\
\text { Time } \\
\text { (minutes) }\end{array}$ & $\begin{array}{c}\text { Final Cr(VI) } \\
\text { Concentration } \\
(\mathrm{mg} / \mathrm{l})\end{array}$ & $\begin{array}{c}\text { Removal } \\
\text { Cr(VI) } \\
(\%)\end{array}$ \\
\hline & 120 & 84.8 & 56.24 \\
\hline \multirow{5}{*}{0.6} & 15 & 86.7 & 55.26 \\
\hline & 30 & 83.2 & 57.07 \\
\hline & 60 & 82.6 & 57.38 \\
\hline & 90 & 78.8 & 59.34 \\
\hline & 120 & 72.8 & 62.44 \\
\hline \multirow{5}{*}{0.8} & 15 & 69.1 & 64.34 \\
\hline & 30 & 68.2 & 64.81 \\
\hline & 60 & 64.3 & 66.82 \\
\hline & 90 & 58.2 & 69.97 \\
\hline & 120 & 56.7 & 70.74 \\
\hline \multirow{5}{*}{1.0} & 15 & 6 61.3 & 68.37 \\
\hline & 30 & 54.7 & 71.78 \\
\hline & 60 & 53.7 & 72.29 \\
\hline & 90 & 47.0 & 75.75 \\
\hline & 120 & 43.6 & 77.50 \\
\hline \multirow{5}{*}{1.2} & 15 & $\begin{array}{c}57.2 \\
\end{array}$ & 70.49 \\
\hline & 30 & 50.3 & 74.05 \\
\hline & 60 & 48.1 & 75.18 \\
\hline & 90 & 39.7 & 79.51 \\
\hline & 120 & 34.5 & 82.20 \\
\hline
\end{tabular}

B. Effect of Adsorbent Mass and Stirring Time on Cr (VI) Removal Percentages

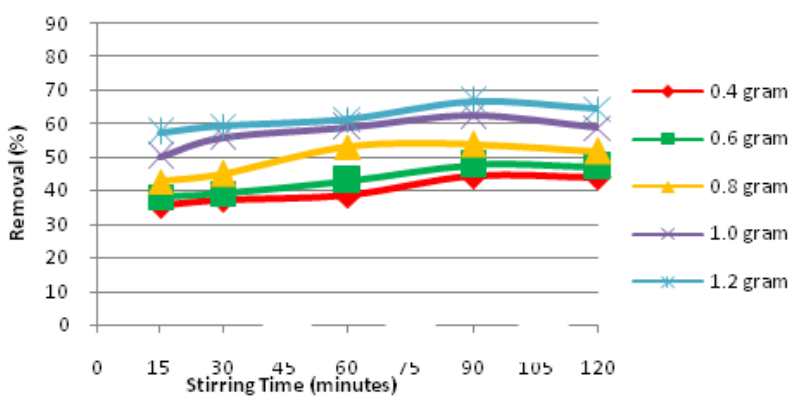

Fig. 1. Graph of Relationship Between Stirring Time (minutes) With Cr (VI) (\%) Removal On Different Adsorbent Masses (grams) For Adsorbents Without Activation

Figure 1 showed that the percent removal of $\mathrm{Cr}(\mathrm{VI})$ had increased gradually every time the mass of the adsorbent increases (grain size is 100 mesh and the stirring speed is 150 rpm). The optimum conditions for adsorbent without activation occured with a mass of 1.2 grams and at the stirring time is 90 minutes. Optimum removal was $66.92 \%$. Stirring time conditions of 120 minutes experience a decrease in removal which can be caused by fully filled the surface of the adsorbent by the adsorbate, or in other words it is in a saturated condition. Adsorbent without activation had reached the optimum absorption capacity in adsorbing $\mathrm{Cr}$ (VI).

At a saturation point, increasing time will reduce the effectiveness of the adsorbent to absorb. This happens because desorption occurs which can release the content that has been absorbed [7]. When the adsorbent surface is saturated or near saturation, two things can happen. First, the second adsorption layer will form above the adsorbate that has been bound to the surface and so on. Second, the second layer and so on are not formed so that the adsorbate that has not been adsorbed will diffuse out of the pore and return to the fluid current [8]. This condition is a balanced or saturated condition so that the adsorption rate and desorption rate are the same. Over time the adsorban condition will go to equilibrium condition so that the adsorption rate will decrease [6].

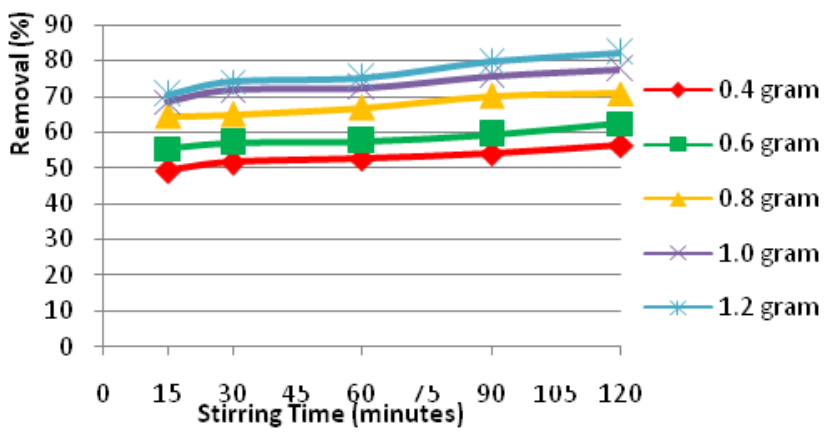

Fig. 2. Graph of Relationship Between Stirring Time (minutes) With Cr (VI) (\%) Removal On Different Adsorbent Masses (grams) For Adsorbents With Activation

Figure 2 showed that the percent metal removal of $\mathrm{Cr}$ (VI) increases with increasing mass of adsorbent and increasing stirring time. The grain size is 100 mesh and the stirring speed was $150 \mathrm{rpm}$. The optimum conditions for activated adsorbent treatment occurred at 1.2 gram adsorbent mass and 120 minutes stirring time with $82.20 \%$ removal percentage.

The amount of adsorbent mass added had an effect on the number of adsorbent granules which means that it affects the amount of metal removal of $\mathrm{Cr}$ (VI) that occurs. The more number of adsorbent granules will increase the surface area of the adsorbent, so that more adsorbate adsorbed. The more mass used, the greater the absorption efficiency of metal ions. [9].

The stirring time is directly proportional to the contact time between the metal particles and the adsorbent. increasing contact time allows more bonding between adsorbents and adsorbate [10]. The situation will turn around when it reaches the saturation point [6]. Activated conditions have a greater volume of cracks or pores. In the activated condition it has a longer saturation point than the condition that has not been activated [11].

\section{Effect of Adsorbent Mass and Stirring Time on $\mathrm{pH}$}

$\mathrm{pH}$ analysis after the adsorption treatment process was carried out in order to determine the effect of adsorbent mass addition and duration of stirring on the final $\mathrm{pH}$ contained in Cr(VI) simulation waste. 
TABLE III. EFFECT OF STIRRING TIME ON FinAL PH VALUE ON DIFFERENT ADSORBENT MASSES FOR ACTIVATED AND NO ACTIVATION ADSORBENTS

\begin{tabular}{|c|c|c|c|}
\hline $\begin{array}{c}\text { Adsorbent } \\
\text { Mass } \\
\text { (gram) }\end{array}$ & $\begin{array}{c}\text { Stirring } \\
\text { Time } \\
\text { (minutes) }\end{array}$ & $\begin{array}{c}\text { Final pH } \\
\text { Without } \\
\text { Activation }\end{array}$ & $\begin{array}{c}\text { Final pH } \\
\text { With } \\
\text { Activation }\end{array}$ \\
\hline \multirow{5}{*}{0.4} & 15 & 6.2 & 6.6 \\
\hline & 30 & 6.3 & 6.7 \\
\hline & 60 & 6.4 & 7.0 \\
\hline & 90 & 6.7 & 7.0 \\
\hline & 120 & 6.3 & 7.2 \\
\hline \multirow{5}{*}{0.6} & 15 & 6.3 & $\begin{array}{l}6.9 \\
\end{array}$ \\
\hline & 30 & 6.3 & 7.0 \\
\hline & 60 & 6.4 & 7.1 \\
\hline & 90 & 6.7 & 7.2 \\
\hline & 120 & 6.4 & 7.2 \\
\hline \multirow{5}{*}{0.8} & 15 & 6.3 & 6.9 \\
\hline & 30 & 6.3 & 7.0 \\
\hline & 60 & 6.5 & 7.2 \\
\hline & 90 & 6.7 & 7.3 \\
\hline & 120 & 6.4 & 7.4 \\
\hline \multirow{5}{*}{1.0} & 15 & 6.3 & 7.2 \\
\hline & 30 & 6.4 & 7.2 \\
\hline & 60 & 6.6 & 7.2 \\
\hline & 90 & 6.7 & 7.3 \\
\hline & 120 & 6.5 & 7.4 \\
\hline \multirow{5}{*}{1.2} & 15 & 6.4 & 7.3 \\
\hline & 30 & 6.4 & 7.3 \\
\hline & 60 & 6.6 & 7.5 \\
\hline & 90 & 6.8 & 7.5 \\
\hline & 120 & 6.5 & 7.6 \\
\hline
\end{tabular}

The results of the final $\mathrm{pH}$ analysis in table 1 are plotted on the graph to determine the effect due to the addition of the adsorbent mass and the duration of stirring. The graphs were presented in Fig 3. and Fig 4.

Figure 3 showed that there was a change in $\mathrm{pH}$ after the adsorption process. The $\mathrm{pH}$ which was initially 6.4 in the adsorbent treatment without activation occurred the highest $\mathrm{pH}$ increase of 6.8 occurred at 1.2 gram adsorbent mass treatment with a stirring time of 90 minutes. This showed an increase in $\mathrm{pH}$ along with increased adsorption of $\mathrm{Cr}$ (VI).

Figure 4 showed the highest $\mathrm{pH}$ of activated adsorbent with a period of 1.2 grams and a time of 120 minutes. The highest $\mathrm{pH}$ was in the same condition as the highest adsorption rate. This showed an increase in $\mathrm{pH}$ along with increased adsorption of $\mathrm{Cr}(\mathrm{VI})$

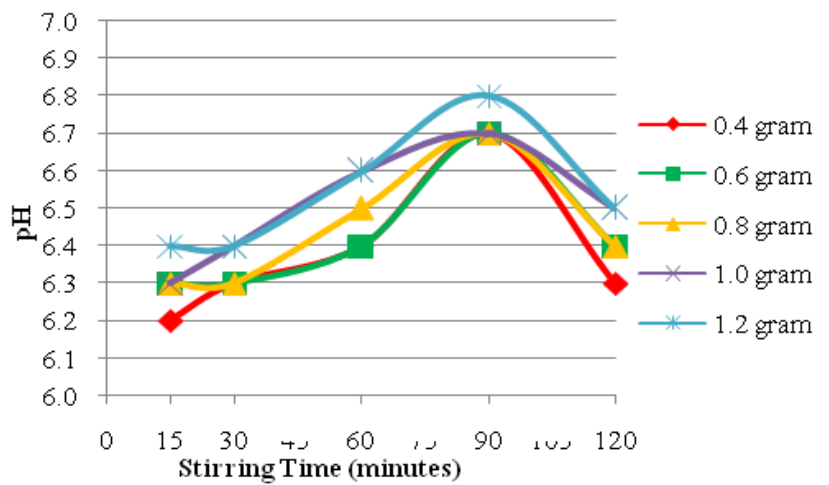

Fig. 3. Graph of Relationship Between Stirring Time (minutes) with Final pH Value on Different Adsorbent Masses (grams) For Adsorbents Without Activation

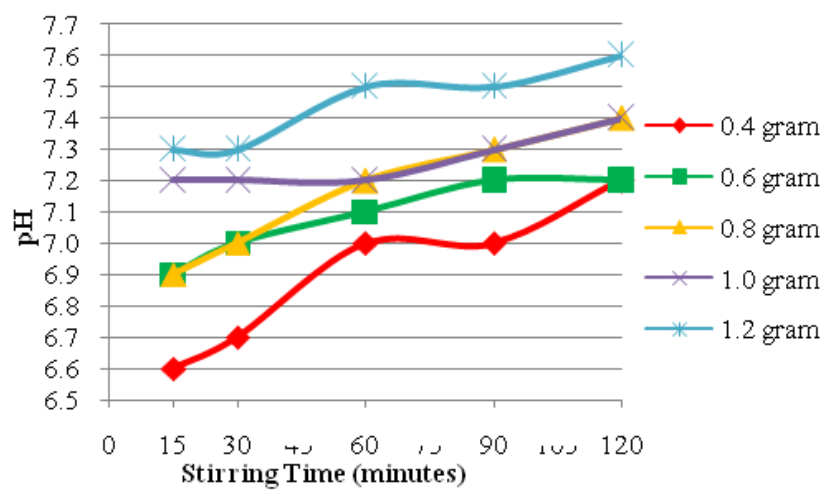

Fig 4. Graph of Relationship Between Stirring Time (minutes) with Final pH Value on Different Adsorbent Masses (grams) For Adsorbents With Activation

This occured due to the nature of $\mathrm{Cr}$ (VI) acid. In the condition that $\mathrm{Cr}(\mathrm{VI})$ is adsorbed, the $\mathrm{PH}$ value increases. The hexavalent chromium ion (VI) has an oxidation number of +6 . The chromate ions are yellow. While the dichromate is orange. The compound formed from hexavalent (VI) chromium ions will be acidic. Chromate ions and dichromates are strong oxidizing agents [12]

The $\mathrm{pH}$ measurement results were still in a neutral range. $\mathrm{PH}$ conditions close to neutral can maximize the adsorbent's absorbent ability from the bones of the cow so that the metal in the solution can be reduced considerably, while the solution with a low $\mathrm{pH}$ has not been able to maximize the absorption capacity of the metal [13].

\section{Adsorption Isotherm Modeling}

Adsorption isotherms are used to determine the adsorption capacity of adsorbents for adsorbates. The adsorption equilibrium isotherm is very important to obtain an equilibrium equation which can be used to determine how much the adsorbate mass is adsorbed by the adsorbent. Isotherm calculations were carried out under optimum conditions of 1.2 gram adsorbent mass in all variations of stirring time with a volume of $100 \mathrm{ml}$ solution. 
1) Isotherm Langmuir

TABLE IV. CALCULATION OF LANGMUIR ISOTHERM ACTIVATED AND NO ACTIVATION ADSORBENT

\begin{tabular}{|c|c|c|c|c|c|c|c|}
\hline \multirow[b]{2}{*}{ Adsor-bent } & \multirow[b]{2}{*}{$\begin{array}{c}\text { Adsorbent } \\
\text { Mass (gram) }\end{array}$} & \multirow[b]{2}{*}{$\begin{array}{c}\text { Stirring } \\
\text { Time (min) }\end{array}$} & \multirow[b]{2}{*}{$\begin{array}{c}\text { Initial } \\
\text { Concentratian }\left(\mathrm{C}_{0}\right) \\
(\mathrm{mg} / \mathrm{L})\end{array}$} & \multirow[b]{2}{*}{$\begin{array}{c}\text { Final Concentration } \\
\left(\mathrm{C}_{\mathrm{e}}\right)(\mathrm{mg} / \mathrm{L})\end{array}$} & \multicolumn{3}{|c|}{ Isotherm Langmuir } \\
\hline & & & & & $\begin{array}{c}\mathbf{x} / \mathbf{m} \\
(\mathrm{mg} / \mathrm{g})\end{array}$ & $1 / C_{e}$ & $1 /(\mathbf{x} / \mathbf{m})$ \\
\hline \multirow{5}{*}{ Non-Activated } & 1.2 & 15 & 193.8 & 82.4 & 9.28 & 0.012 & 0.108 \\
\hline & 1.2 & 30 & 193.8 & 78.5 & 9.61 & 0.013 & 0.104 \\
\hline & 1.2 & 60 & 193.8 & 74.8 & 9.92 & 0.013 & 0.101 \\
\hline & 1.2 & 90 & 193.8 & 64.1 & 10.81 & 0.016 & 0.093 \\
\hline & 1.2 & 120 & 193.8 & 68.7 & 10.43 & 0.015 & 0.096 \\
\hline \multirow{5}{*}{ Activated } & 1.2 & 15 & 193.8 & 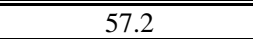 & 11.38 & 0.017 & 0.088 \\
\hline & 1.2 & 30 & 193.8 & 50.3 & 11.96 & 0.020 & 0.084 \\
\hline & 1.2 & 60 & 193.8 & 48.1 & 12.14 & 0.021 & 0.082 \\
\hline & 1.2 & 90 & 193.8 & 39.7 & 12.84 & 0.025 & 0.078 \\
\hline & 1.2 & 120 & 193.8 & 34.5 & 13.28 & 0.029 & 0.075 \\
\hline
\end{tabular}

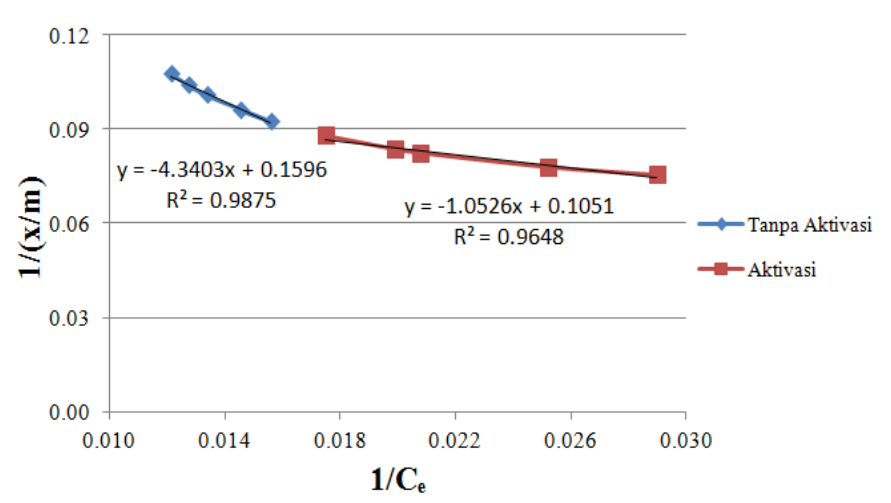

Langmuir isotherm model based on calculation data Table 4. graphs can be made by plotting the value $1 / \mathrm{Ce}$ as the $\mathrm{x}$ axis against the value $1 /(\mathrm{x} / \mathrm{m})$ as the y axis. From Figure 5. the Langmuir isotherm graph for adsorbent without activation obtained a linear equation that is $\mathrm{y}=-4.3403 \mathrm{x}+0.1596$ with a value of $\mathrm{R}^{2}=0.9875$. Whereas, the activated adsorbent obtained a linear equation that is $\mathrm{y}=-1.0526 \mathrm{x}+0.1051$ with a value of $R^{2}=0.9648$.

Fig 5. Graph of the Relationship between 1 / Ce with 1 / (x / m) on Langmuir Isotherm for Activated and Non-Activated Adsorbents

\section{2) Isotherm Freundlich}

TABLE V. CALCULATION OF FREUNDLICH ISOTHERM ACTIVATED AND NO ACTIVATION ADSORBENT

\begin{tabular}{|c|c|c|c|c|c|c|c|}
\hline \multirow[b]{2}{*}{ Adsorbent } & \multirow[b]{2}{*}{$\begin{array}{l}\text { Adsorbent Mass } \\
\quad \text { (gram) }\end{array}$} & \multirow[b]{2}{*}{$\begin{array}{c}\text { Stirring } \\
\text { Time (min) }\end{array}$} & \multirow[b]{2}{*}{$\begin{array}{c}\text { Initial } \\
\text { Concentratian } \\
\left(\mathrm{C}_{0}\right)(\mathrm{mg} / \mathrm{L})\end{array}$} & \multirow[b]{2}{*}{$\begin{array}{c}\text { Final } \\
\text { Concentration } \\
\left(\mathbf{C}_{\mathrm{e}}\right)(\mathrm{mg} / \mathrm{L})\end{array}$} & \multicolumn{3}{|c|}{ Isotherm Freundlich } \\
\hline & & & & & $\mathrm{x} / \mathrm{m}(\mathrm{mg} / \mathrm{g})$ & $\log \mathrm{C}_{\mathrm{e}}$ & $\log \mathbf{x} / \mathrm{m}$ \\
\hline \multirow{5}{*}{ Non-Activated } & 1.2 & 15 & 193.8 & 82.4 & 9.28 & 1.916 & 0.968 \\
\hline & 1.2 & 30 & 193.8 & 78.5 & 9.61 & 1.895 & 0.983 \\
\hline & 1.2 & 60 & 193.8 & 74.8 & 9.92 & 1.874 & 0.996 \\
\hline & 1.2 & 90 & 193.8 & 64.1 & 10.81 & 1.807 & 1.034 \\
\hline & 1.2 & 120 & 193.8 & 68.7 & 10.43 & 1.837 & 1.018 \\
\hline \multirow{5}{*}{ Activated } & 1.2 & 15 & 193.8 & 57.2 & 11.38 & 1.757 & 1.056 \\
\hline & 1.2 & 30 & 193.8 & 50.3 & 11.96 & 1.702 & 1.078 \\
\hline & 1.2 & 60 & 193.8 & 48.1 & 12.14 & 1.682 & 1.084 \\
\hline & 1.2 & 90 & 193.8 & 39.7 & 12.84 & 1.599 & 1.109 \\
\hline & 1.2 & 120 & 193.8 & 34.5 & 13.28 & 1.538 & 1.123 \\
\hline
\end{tabular}




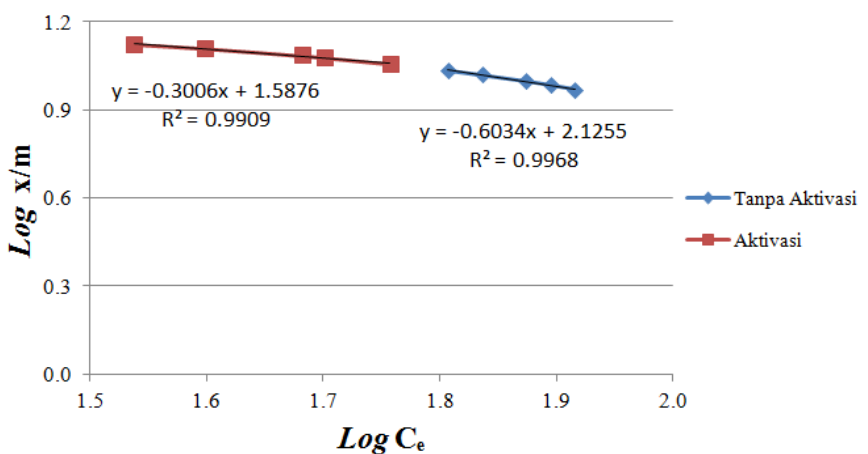

Fig 6. Graph of the Relationship between 1 / Ce with 1 / (x / m) on Freundlich Isotherm for Activated and Non-Activated Adsorbents

Freundlich's isotherm model is based on calculation data. Table 5. Graphs can be made by plotting the value of Log Ce as the $\mathrm{x}$ axis of the $\log \mathrm{x} / \mathrm{m}$ value as the $\mathrm{y}$ axis. From Figure 6. The Freundlich isotherm graph for adsorbent without activation obtained a linear equation that is $\mathrm{y}=-0.6034 \mathrm{x}+$ 2.1255 with a value of $\mathrm{R}^{2}=0.9968$. Whereas the activated adsorbent obtained by linear equation is $\mathrm{y}=-0,3006 \mathrm{x}+1,5876$ with the value $R^{2}=0,9909$.

\section{3) Mechanism of Adsorption Isotherms}

TABLE VI. VALUE OF THE LANGMUIR AND FREUNDLICH ADSORPTION ISOTHERM MECHANISMS

\begin{tabular}{|c|c|c|}
\hline \multirow{2}{*}{ Isotherm Parameter } & Without Activation & With Activation \\
& \multicolumn{3}{|c|}{ Isoterm Langmuir } \\
\hline \hline \multicolumn{3}{|c|}{} \\
\hline Equation & $\mathrm{y}=-4.3403 \mathrm{x}+0.1596$ & $\mathrm{y}=-1.0526 \mathrm{x}+0.1051$ \\
\hline $\mathrm{qm}(\mathrm{mg} / \mathrm{g})$ & 6.27 & 9.51 \\
\hline $\mathrm{B}$ & 0.037 & -0.100 \\
\hline \hline $\mathrm{R}^{2}$ & 0.9875 & 0.9648 \\
\hline \hline \multicolumn{3}{|c|}{ Isoterm Freundlich } \\
\hline $\mathrm{Equation}$ & $\mathrm{y}=-0.6034 \mathrm{x}+2.1255$ & $\mathrm{y}=-0.3006 \mathrm{x}+1.5876$ \\
\hline $\mathrm{K}(\mathrm{mg} / \mathrm{g})$ & 133.51 & 38.69 \\
\hline $\mathrm{n}$ & -1.657 & -3.327 \\
\hline $\mathrm{R}^{2}$ & 0.9968 & 0.9909 \\
\hline
\end{tabular}

The determination of the Langmuir and Freundlich adsorption isotherm models can be seen by looking at the $\mathrm{R}^{2}$ value which is close to the 1 . The suitable isotherm model is an isotherm model with a $\mathrm{R}^{2}$ value that is higher and closer to the value 1 [14]. From the data in Table 6 . it can be seen that the comparison of $\mathrm{R}^{2}$ values from the equation of Langmuir and Freundlich adsorption isotherms showed that for adsorbents without Freundlich isotherm activation had an $\mathrm{R}^{2}$ value close to a value of 1 which is equal to 0.9968 , while the Langmuir $\mathrm{R}^{2}$ value was 0.9875. And for the activated adsorbent the Freundlich isotherm also had an $\mathrm{R}^{2}$ value close to the value of 1 which is equal to 0.9909 , while the $R^{2}$ value of the Langmuir isotherm was equal to 0.9648 . It can be concluded that the adsorption that occurs in $\mathrm{Cr}$ (VI) metal by activated adsorbent and without activation shows a tendency to follow the Freundlich isotherm adsorption model where the $\mathrm{R} 2$ value is closer to 1 compared to the $\mathrm{R} 2$ value of the Langmuir isotherm. Freundlich's isotherm adsorption model emphasizes that the maximum adsorption capacity occured due to the presence of more than one surface layer (multilayer) of adsorbate on the surface of the adsorbent assuming the molecule is adsorbed by the site (where the reaction on the surface of the adsorbent) is fixed, each site can hold more than one adsorbate molecule, and there are differences in binding energy at each site [15].

According to Varenta [15], stated that the adsorption of copper metal using beef bone adsorbent without activation tends to follow the Freundlich isotherm adsorption model with a value of $\mathrm{R} 2=0.7113$. According to Arifuddin [17], stated that the adsorption of $\mathrm{Cr}$ (VI) metal using activated corn cob adsorbent tended to follow Freundlich isotherm adsorption model with a value of $\mathrm{R} 2=0.810$.

\section{CONCLUSION}

Based on the research that has been done, it can be concluded that as follows :

1. Cow bone waste can be used as an adsorbent in adsorbing hexavalent chromium metal [Cr (VI)] contained in simulas waste.

2. Adsorbent adsorption ability optimum for cow bone waste occurs at 1.2 gram adsorbent mass with stirring time of 90 minutes at $66.92 \%$ for adsorbent without activation and 1.2 gram adsorbent mass with 120 minutes stirring time of $82.20 \%$ for adsorbent activated $5 \%$ $\mathrm{Na}_{2} \mathrm{CO}_{3}$.

3. Adsorption isotherm on adsorbent of cow bone waste followed Freundlich model with R2 $=0.9968$ for adsorbent without activation and for activated adsorbent with R2 $=0.9909$.

\section{REFERENCES}

[1] L.R. Hossner, R.H. Loeppert, R.J. Newton, P.J. Szaniszlo, in collaboration with Attrep Jr., M, "Phytoaccumulation of chromium, uranium, and plutonium in plant systems", Amarillo National Resource Center for Plutonium, 1998-3, pp. 1-31, May 1998.

[2] D.W. Dwiasi, dan D. Kartika, "Speciation of Cr (III) and Cr (VI) in Electroplating Industrial Liquid Waste", Chemical Study Program. Jenderal Soedirman University. Purwokerto, 2008

[3] M. Akbar, "Effect of Contact Time on the Adsorption Power of Cattle Bone on Lead Ions (Pb2+)", Res. j. Makassar State University. Makassar, 2012

[4] J.A. Wilson, L.D. Pulford, Thomas,"Sorption Of $\mathrm{Cu}$ and $\mathrm{Zn}$ by Bone Charcoal", Environmental Geochemistry and Health, Netherland, vol 25, pp. 51-56, March 2003.

[5] A.N. Muna," Adsorption Kinetics of Activated Carbon from Banana Rods as Adsorbents for Absorption of $\mathrm{Cr}$ (VI) Metal Ions in Industrial Wastewater", Final Project II. Chemistry Department. FMIPA. Semarang State University.2011,

[6] I. Langmuir, "The constitution and fundamental properties of solids and liquids", J. Am. Chem. Soc., Vol. 38 (11), pp. 2221-2295, November 1916.

[7] Fitriyana, E. Safitri," Utilization of Chicken Egg Shells as Adsorbents to Improve the Quality of Cooking Oil", Chemical Engineering 
Department. Samarinda State Polytechnic, 2015.

[8] R. Wijayanti,“Active Charcoal From Sugarcane Waste As An Adsorbent For Refining Used Cooking Oil”, Thesis. Bogor Agricultural Institute, 2009.

[9] P. Alifaturrahma, O.H. Cahyonugroho," Utilization of Kepok Banana Skin as Adsorbent for the Removal of Cu Metal", Thesis. Environmental Engineering Program. Faculty of Engineering. University of National Development "Veteran" East Java. Surabaya, 2017.

[10] I. Syauqiah, M. Amalia, dan H.A. Kartini, "Analysis of Time Variation and Stirring Speed in Adsorption Process of Heavy Metal Waste with Active Charcoal, Info Teknik, vol. 12. No 1, 2011.

[11] Zhonghua Hu., M.P. Srinivasan., Yaming Ni. "Novel Activation Process for Preapring Highly Microporous and Mesoporous Activated Carbons", Carbon., vol. 39, pp. 877-886, May 2001.
[12] Yefrida, Yuniartis. Final report of BBI research. 2011

[13] M.F. Setyono, "Utilization of Cattle Bone Waste as Adsorbent for Absorbing Cadmium Metal (Cd) Using Na2CO3 Activation", Thesis. Environmental Engineering Department. FTSP.UII.Yogyakarta, 2009.

[14] N. Kurniaty,"Equilibrium of Adsorption of Oil Residue from Liquid Waste of Palm Oil Mill (Pome) using Active Peat", Essay. Chemical Engineering. Faculty of Engineering UR. Pekanbaru, 2008.

[15] Z.A.S. Varenta,"Utilization of Cattle Bone Waste as Adsorbent for Absorbing Copper (Cu) Metal Using Na2CO3 Activation”, Essay. Environmental Engineering Study Program. FTSP. Indonesian Islamic University, 2016.

[16] W. Arifuddin,"Effect of Cr (VI) Ion Concentration on Corncob (Zea Mays) Activated Carbon Adsorption Power", Essay. STKIP Pembangunan Indonesia. Makassar, 2017. 